\title{
CIF/IFC Gold Medal Winners Gagnants de la médaille d'or de l'institut
}

\begin{abstract}
Alain Neveu
La Cité

Alain Neveu s'inscrit au programme de Techniques forestières en septembre 2000, car il a un vif intérêt pour la flore et la faune. Alain est très motivé et vise toujours l'excellence dans tous ses travaux. Apprécié de ses professeurs et des autres élèves, c'est avec enthousiasme et initiative qu'il relève chaque nouveau défi.
\end{abstract}

Il était représentant de classe et

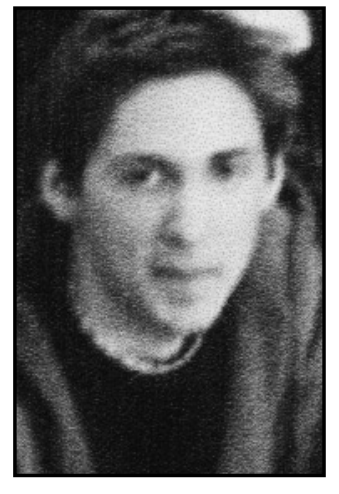
récipiendaire de la Médaille d'or pour ses résultats scolaires remarquables et sa participation à de nombreuses activités étudiants au collège.

Après l'obtention de son diplôme en juin 2002, Alain désire poursuivre des études universitaires dans un domaine relié à l'environnement.

Alain attribut sa réussite scolaire au support de ses proches et à sa grande discipline personnelle.

\section{Debora Johnstone}

Northern Alberta Institute of Technology

Deborah Johnstone was this year's recipient of the Gold Medal in the Forest Technology program through NAIT. This dedicated student also received ten other awards and scholarships over the past two years. In her last year at NAIT, she actively participated on the grad committee and spearheaded the new yearbook format.

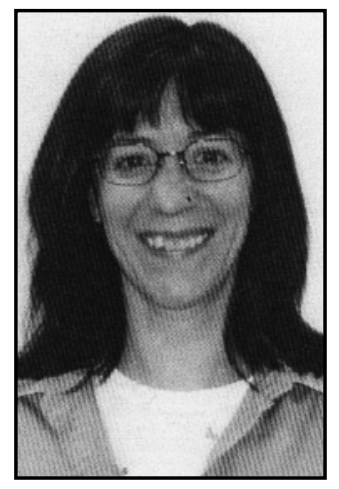
Deborah originally made the transition into forestry after a 13 year teaching career which afforded her the opportunity to work in many countries as well as across Canada. Deborah will be spending her second summer at Slocan in Mackenzie, BC, and eventually hopes to return to Alberta to pursue her interest in Silviculture. Her long-term goal is to return to the classroom in a capacity that would allow her to incorporate both of her career experiences.

\section{Dominic Aspirault Cégep de la Gaspésie}

Dominic Aspirault, finissant dans le programme de technologie forestière au Cégep de la Gaspésie et des Iles s'est vu attribué le medaille d'or de l'Institut forestier canadien pour la qualité de son dossier

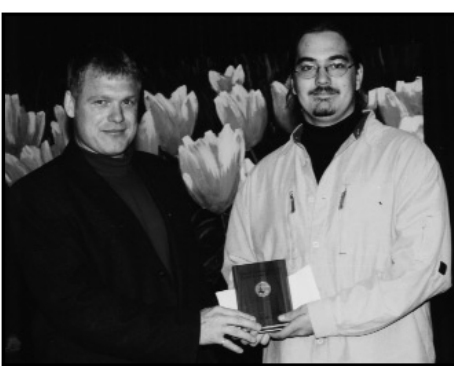

Bruce Jones (L) Dominique Aspirault (R). académique, mais aussi pour son leadership et les autres qual- ités personnelles et professionnelles qu'il a su démontrer tout au long de sa formation par le biais des projets scolaires et parascolaires dans lesquels il a su s'impliquer voire, s'engager.

Félicitations à Dominic! Nous te souhaitons une carrière fructueuse, truffée de défis qui sauront te stimuler et te donner la fierté d'être forestier!

\section{Jean-François Morin \\ Université de Moncton}

Cette année, le finissant de la Faculté de foresterie de l'Université de Moncton qui s'est mérité la Médaille d'or de l'IFC est Jean-François Morin. Originaire de Cornwall, Île-duPrince-Édouard, JeanFrançois s'est distingué par son excellent rendement académique et par son implication dans son milieu. Entre

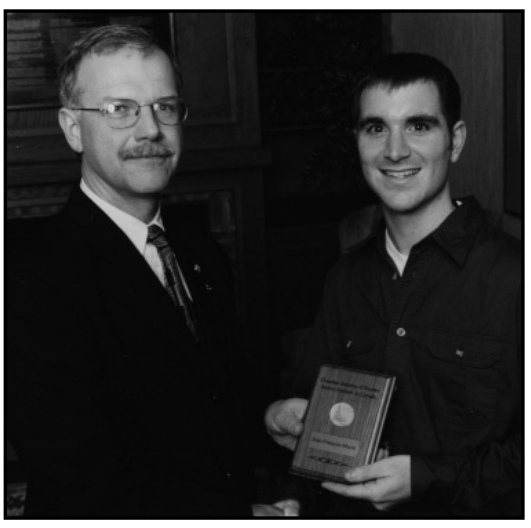
Len Moores (L) Jean-Francois Morin (R). autres, il a été membre de l'équipe de badminton et du comité Envert de notre campus. Il a aussi été bénévole à l'Hôpital régional d'Edmundston et a donné plusieurs concerts de piano sur le campus. Jean-François s'est mérité une bourse du CRSNG et a l'intention de poursuivre ses études au niveau de la maîtrise à la Faculté de foresterie dès l'été 2002.

\section{Erin Michelle Baker \\ British Columbia Institute of Technology}

Based on overall grade-point average, sports participation and community activities, Erin Baker has been selected as the CIF gold medal recipient for this year from the graduating class of the Renewable Resources Forestry program at B.C.I.T.

Erin is a second year Forestry student currently enrolled in the fourth of

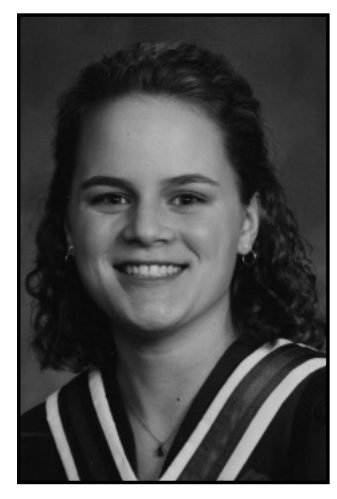
four terms required for a diploma in Forestry. Erin has a combination of high GPA, demonstrated leadership skills, and involvement in sporting activities including playing basketball, volleyball, and softball, as well as coaching bowling. Within the B.C.I.T. community, she regularly volunteers to speak to groups of prospective forestry students. Erin has participated in anti-racism campaigns that have received provincial recognition. She gets along exceptionally well with fellow students and can be relied upon to be an enthusiastic participant in classroom on extracurricular activities. 


\section{Hélène Daigle \\ Collège Boréal}

Hélène Daigle est la lauréate de la Médaille d'or 2002 de l'Institut forestier du Canada. Origniaire de SaintLéonard-Parent, au NouveauBrunswick, Hélène s'est démarquée tout au long de ses études en Technologie forestière au Collège Boréal par son rendement scolaire remarquable. C'est une étudiante consciencieuse et autonome qui manifeste un grand intérêt pour le domaine de la foresterie. Elle n'hésite

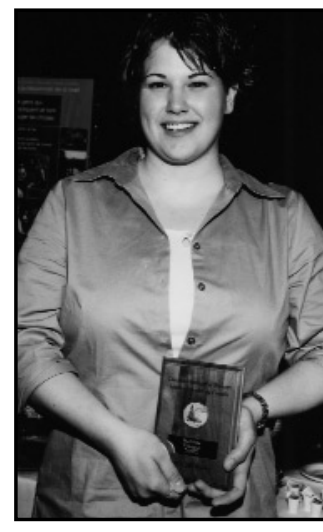
pas à appuyer ses confrères et consoeurs de classes dans leurs travaux et leurs études. De plus, elle a été un pilier de l'équipe féminine de volley-ball intercollégial du Collège au cours des trois dernières années.

Durant le dernier semestre, Hélène Daigle a fait un stage de deux mois chez RégeNord, entreprise-conseil en foresterie et sylviculture, à Kedgwick, au Nouveau-Brunswick. Les liens qu'elle a su établir et son excellent travail durant son stage lui permettront sûrement de se décrocher un emploi à temps plein. Nous lui souhaitons donc beaucoup de succès dans sa carrière.

\section{Seth Wing \\ Sault College}

I was born in Sault Ste. Marie on April 7, 1981. I completed high school by graduating from Sir James Dunn High School in 2000 as an OSSD graduate. I enrolled in Sault College as a Forestry Technician in September 2000 and plan to graduate in the spring of 2002. I have applied to attend Lakehead University in the fall of 2002 in the Forestry program

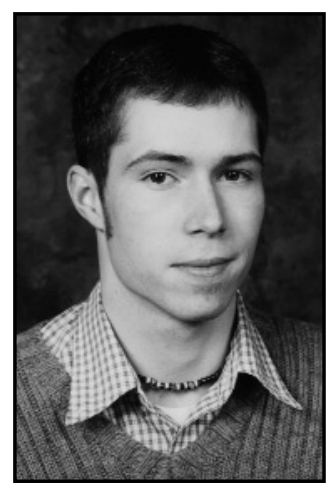

I have worked throughout high school with a paper route and as a ski technician at the local ski hill. My first real work experience was in Walkerton with the water crisis that happened in the summer of 2000. I worked as part of a disinfections response team. My duties were to test the water in residential and business locations. Last summer I completed the forest fire pre-fit course as well as the s100 firefighter training program and was employed as a firefighter posted to the Fort Frances response team. I have been offered employment with the team again this year.

My family, with a younger brother and sister, all live at home in Sault Ste Marie. We have a family cabin in our woodlot near here and the entire family including my grandparents run a small maple syrup operation as a hobby each spring. I have spent a lot of time at the woodlot and enjoy the outdoors and hope to work in the forestry industry with a special interest in environmentally sustainable operations.

\section{William Luke Martin \\ Maritime Forest Ranger School}

Will came to the Maritime Forest Ranger School as a single student (20 years of age). He brought a strong background of

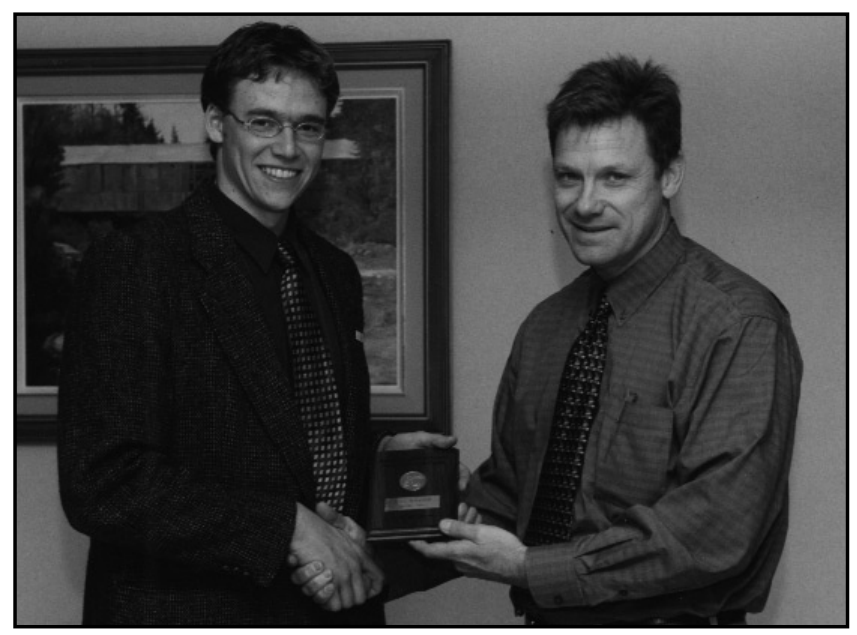

Will Martin (L) Julius Tarjan (R).

work and study in all aspects of eco-forestry, which he had acquired at Jim Drescher's Windhorse Farm in Bridgewater, Nova Scotia. He also brought an incredibly open and inquisitive mind, an insatiable thirst for knowledge, and an uncanny holistic perspective of the forest. Will was a very strong student with superior communication and interpersonal skills and distinguished himself early on as a very capable and ever-willing helper to his classmates. Upon graduation, Will was also the recipient of the Nova Scotia Forest Technicians Association Prize, awarded to the Nova Scotia student with the highest academic standing. He also won the George and Myrna Melvin Memorial Prize, awarded to the student with the highest overall standing in map and compass related courses. Will is an extremely courteous and personable individual, a real asset to the forestry community, and we are very proud to present him to you.

\section{Émilie St-Jean \\ Cégep de Baie-Comeau}

Mme Émilie St-Jean obtiendra son diplôme d'études collégiales en mai prochain avec une mention d'excellence. C'est une personne qui s'implique beaucoup dans son milieu. Elle a été choisie à plusieurs reprises pour représenter les élèves du programme de technologie forestère dans des évènements provinciaux et régionaux. Talentueuse et éveillée, elle n'hésite

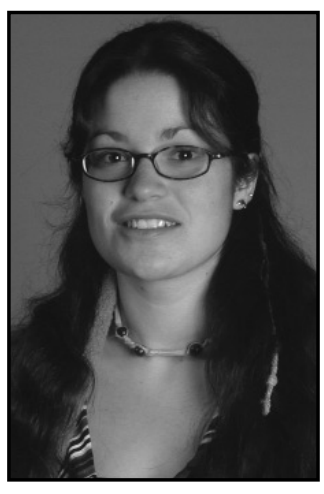
pas à proposer des activités de promotion ou des rencontres pour élargir ses horizons. Émilie a été une stagiaire recherchée par les employeurs et identifée comme efficace et débrouillarde. Son sens de l'organisation et sa capacité de travailler en équipe lui seront toujours utiles dans sa vie professionnelle.

\section{Joël Bérubé Cégep de Rimouski}

Me voila sur le point de terminer un diplôme d'études collégiales en Technologie forestière. Ce parcours de vie m'apparaît comme étant un choix d'avenir judicieux. Il n'est pas 
sans dire que les controverses au sujet de la foresterie font partie des agents de stress concernant mon avenir mais enfin, je crois que cette mention d'honneur décernée par l'Institut Forestier du Canada est un élément de réconfort. Je crois que l'effort est toujours récompensé et en voilà une preuve. De nos jours, il devient important de performer dans ce que nous entreprenons afin d'atteindre certains objectifs de vie professionnelle.

Durant mes études collégiales, j'ai eu la chance de pouvoir approfondir mes connaissance concernant les différentes structures régissant la forêt du Québec. Avec les lois et les normes du gouvernement, les besoins des industries et ceux des utilisateurs de la forêt, la foresterie m'apparaît comme un monde perpétuellement conflictuel. Je crois qu'il faut améliorer ce domaine afin que tous les gens concernés par la foresterie soient sur la même longueur d'onde et que la forêt elle-même soit enfin perçue comme une ressource indispensable dont l'importance dépasse largement les bénéfices monétairs.

Ainsi après avoir terminé un DEC en foresterie, le fait de continuer mes études au niveau universitaire serait pour moi un outil très utile pour participer activement à l'amélioration des structures régissant la forêt. Il est important pour moi de m'impliquer dans ce domaine, car la forêt est à la base de la vie et malheureusement, l'être humain semble parfois l'oublier.

\section{Molly Hink}

Nicola Valley Institute of Technology

Molly Hink was chosen by the NRT Faculty for the CIF Gold Me d a l because of her hard work and dedication to her studies. Molly is one of those individuals who could be described by the old saying "still waters run deep." She completed the very rigorous Nat-

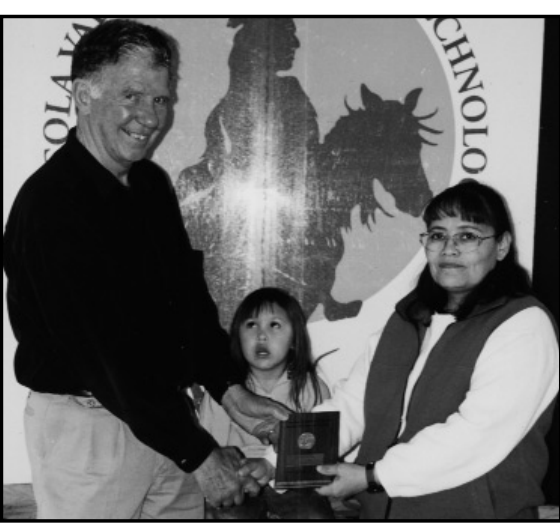

Norm Hansen presents medal to Molly Hink. ural Resources

Technology Diploma on schedule with very solid grades at the same time looking after a larger than average family. Molly is a good candidate to take her formal learning experience into the work force and serve her employer well.

Ms. Hink is shown receiving her award from Norm Hansen a professional Forester, representing Foresters of BC, and standing in for Rod Willis, the CIF representative for our region.

\section{Julie Langevin}

Université Laval

Lors de la remise des joncs qui s'est tenue à l'Université Laval en avril dernier, Julie Langevin a été désignée récipiendaire de la médaille d'or de l'IFC pour la Faculté de Foresterie et de Géomatique.

En entrant au baccalauréat en aménagement et environnement forestiers en 1998, Julie Langevin établit une dynastie de forestiers

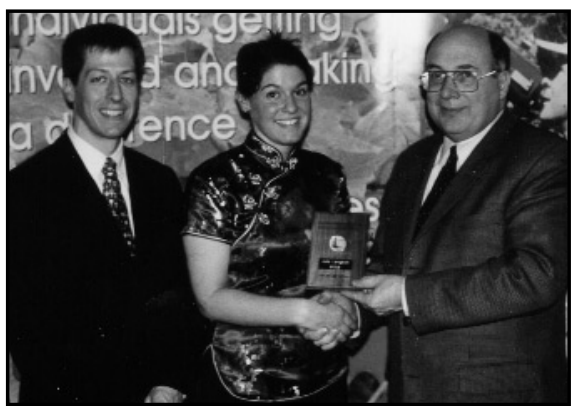

Vincent Roy (L), Julie Langevin, Claude Godbout (R). puisque son père et sa mère sont tous deux ingénieurs forestiers, d'ailleurs très connus et appréciés dans leur milieu de travail.

$\mathrm{Au}$ cours de ses études, en plus d'être une première de classe, elle a été de tous les combats, représentante à l'Association des étudiants en foresterie de l'Université Laval, bénévole puis gérante du café étudiant et présidente du comité des finissants.

Elle s'est méritée de nombreux honneurs durant son parcours académique, dont une bourse d'excellence de l'Association des manufacturiers de bois de sciage du Québec en 1999 et une bourse de recherche de $1^{\text {er }}$ cycle du Conseil de la recherche en sciences naturelles et génie (CRSNG) en 2000. Nous lui souhaitons bonne chance pour la poursuite de sa carrière.

\section{Ryan Sandry SIAST}

The Saskatchewan Section presented the CIF Gold Medal to Mr. Ryan Sandry. Ryan's leadership in sporting activities, civic involvement and in his academic life make him a very fitting recipient of the award. In addition to his school work and other outside

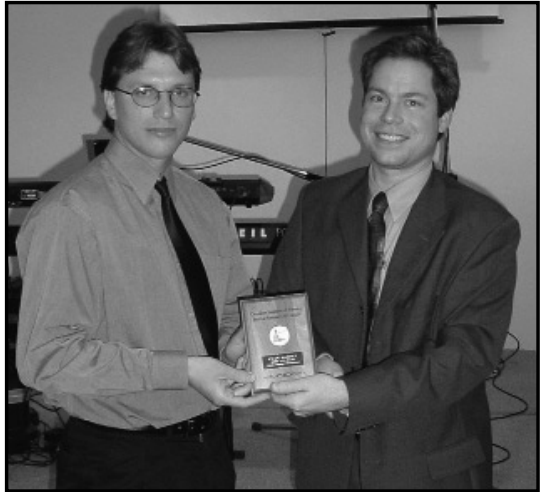

Michael Mclaughlan (R), Chair and Director of SK Section awarding the Gold medal to Ryan Sandry. interests, Ryan was

the student liaison on the CIF SK Section council. His input to discussions and interest in all matters concerning the Institute were also evidence of his leadership.

\section{Cathy Leduc}

Technologie forestière au Cégep

À la fin de la session d'hiver 2002, l'étudiante finissante en Technologie forestière, Cathy Leduc, s'est mérité la médaille du mérite forestier.

Cathy a obtenu cette distinction en raison de ses résultats académiques et de son engagement dans son milieu collégial. Sa passion pour la forêt a également motivé les enseignants du

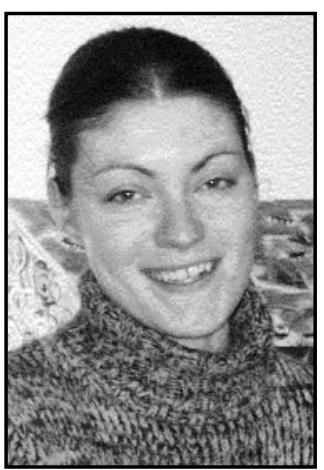


programme à privilégier la candidature de Cathy. Depuis toujours, Cathy manifeste un grand intérêt pour la forêt et son habitat. Cet enthousiasme s'est particulièrement révélé pendant sa formation en Technologie forestière où elle a même été en nomination au Gala reconnaissance 2002, un événement mettant en valeur les meilleurs élèves.

La médaille est attribuée à chaque année au Canada dans les programmes d'enseignement des établissements d'enseignement secondaire, collégial et universitaire, par l'Institut forestier du Canada, une organisation quasi centenaire qui préconise la mise en œuvre de pratiques forestières réfléchies.

\section{Étienne Boulay}

Cégep de Sainte-Foy

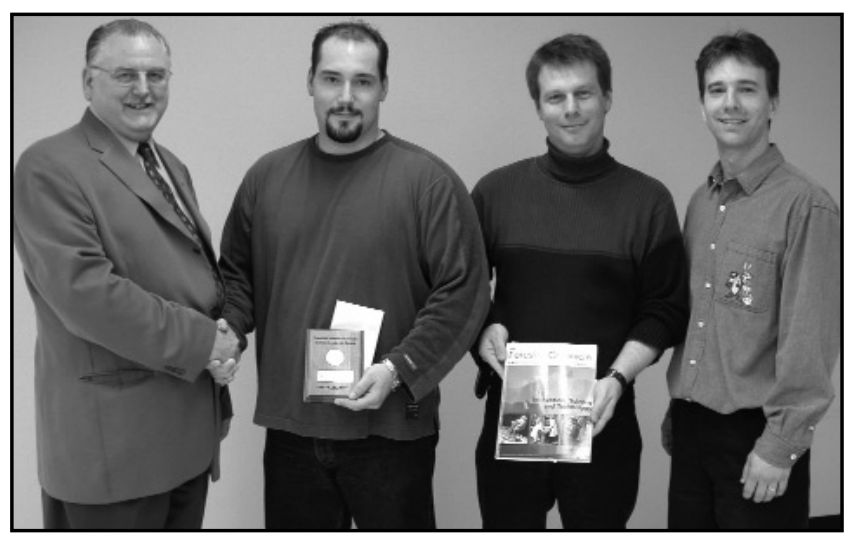

Natif de Gaspé, Étienne obtient son DES à l'école secondaire De Rochebelle à Sainte-Foy. Il complète ensuite un DEC en sciences humaines avant de s'inscrire en Technologie forestière.

Organisateur chevronné, il est très engagé dans la réalisation d'activités parascolaires tout au long de ses études.

L'été, il travaille pour la Direction de la recherche forestière du ministère des Ressources naturelles. Passionné, il rêve de faire progresser la foresterie au cours de sa carrière, qui s'annonce très prometteuse.

En plus de la médaille d'or de l'Institut forestier du Canada, Étienne a mérité un certificat-cadeau de 200\$ offert par la firme de consultants CFRQ et une bourse de 100\$, gracieuseté du Syndicat des producteurs de bois de la Beauce.

\section{Stephen Lenio Malaspina \\ University-College}

Stephen Lenio, this year's CIF Gold Medal recipient, is a Vancouver Island lad who graduated from our program in April. Throughout his 2 years at Malaspina University-College, he maintained a first place standing amongst his

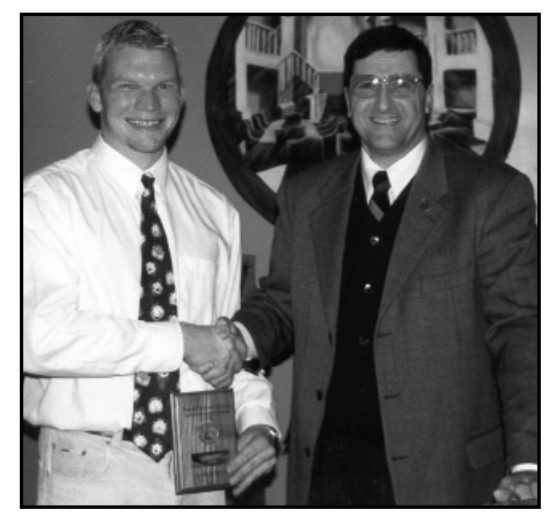

Seve Lenio (L) receiving his Gold Medal from Michel Vallee. peers. His attitude and disposition in class were beyond reproach. Steve encouraged participation and set the standard for his colleagues. He was always ready to initiate action on class projects, fund raisers, and promote involvement in the community. Stephen intends to go on with his studies but plans to work for a few years beforehand. This summer, Steve is working as an engineer with Interfor in coastal BC.

\section{Michel Vallee}

\section{Carmen Minor}

College of New Caledonia

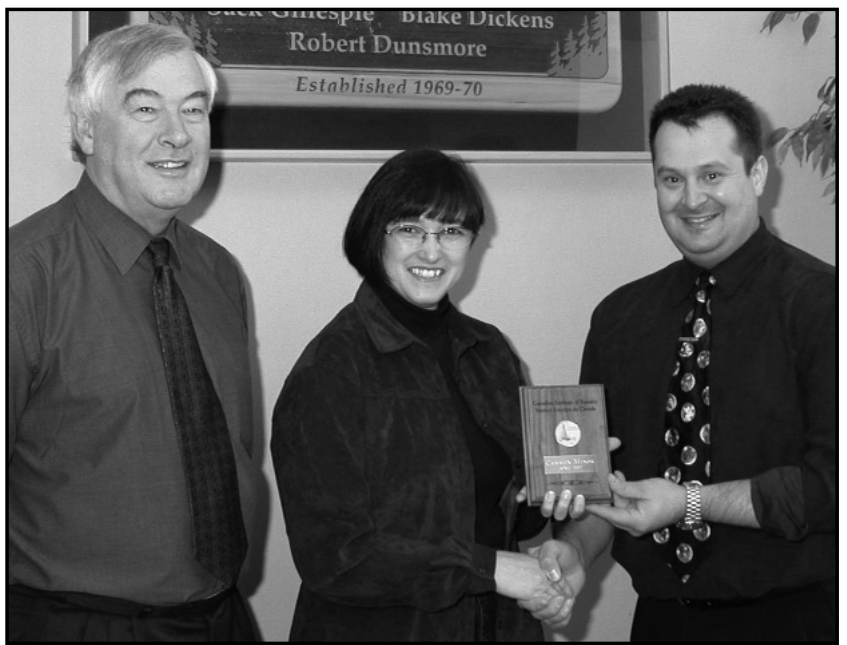

Ben Malcolm (L), Dean, Science and Technology, CNC, Carmen Minor, Dennis Pelletier, CR Section Chair.

This year, the faculty at CNC have recommended Carmen Minor for this prestigious award. She is shown in this award photo with Denis Pelletier, chair of the Cariboo Section on the right and Ben Malcolm, Dean of Science and Technology at CNC on the left. Carmen has been an outstanding student in the Forest Resource Technology program at the College of New Caledonia.

Carmen grew up in central Ontario, and was trained and worked as a laboratory technician in the health sector. A move to Kamloops meant a change from the health sector to the mining sector where she worked for five years as an environmental technician. Carmen and her husband Bob have successfully raised their two daughters, Elaine and Michele.

A career change for Carmen was prompted by a family move to Fraser Lake where her laboratory skills were not in demand. After looking at the opportunities offered in the area, Carmen decided that studying forest technology would be a logical extension of her existing skills. She has spent the past two years commuting the three hours to and from Fraser Lake on a weekly basis, a demonstration of her family support and dedication.

As a mature student, Carmen brought her creativity and tenacity to her academic life. Her optimistic attitude and strong family support have contributed to her outstanding academic performance, maintaining a 4.17 GPA in a demanding program. She is the treasurer of the forestry club and is a committed contributor to all of that group's activities. She has high expectations of herself, and encourages her classmates to participate as fully as she does in program activities. 
Carmen was the first participant in the new Co-op option for the Forest Resource Technology program. She was employed by the B.C. Ministry of Forests Range Section for her first Coop work term last summer and is looking forward to continuing her Co-op placement with the MOF again this year. Her plans are to return to $\mathrm{CNC}$ in the fall or next winter to work towards completion of a degree in forestry and membership in the Association of B.C. Professional Foresters.

\section{Melissa MacPhail \\ Sir Sandford Fleming College}

This independent and self-motivated young lady grew up in Waterloo, Ontario, graduating from Bluevale Collegiate Institute in 1999. Her interest in the outdoors was somewhat ironically initiated by a high school coop placement with the City of Waterloo Cemetery Services. This motivated Melissa to seek higher education at

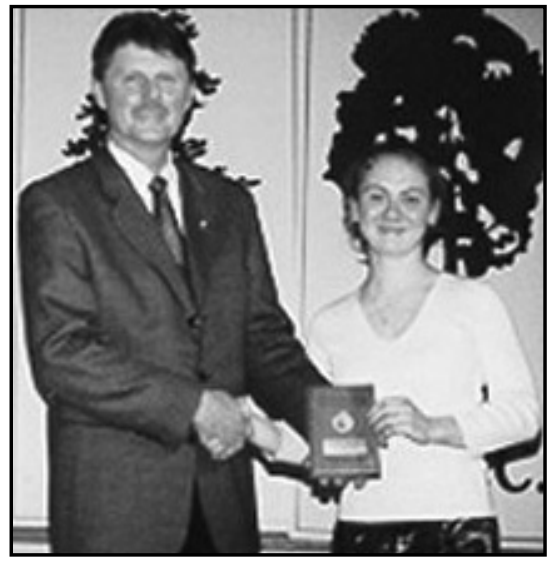

Bruce Ferguson (L) presents medal to Melissa MacPhail.
Sir Sandford Flem-

ing, where Forestry was the logical program to fulfill her interest in ecology and forests. While at Sir Sandford Fleming College, Melissa encouraged her peers intellectually and socially through example, by being a strong student leader. Upon graduation Melissa plans to work for the Ontario Ministry of Natural Resources fire fighting in Kenora. Further education at Sir Sandford Fleming College in the fish and wildlife area and more forestry education at university are included in her future plans.

\section{Brendan Brabendar \\ University of Alberta}

Brendan Brabendar was chosen as this years CIF gold medal recipient for outstanding academic scholarship, citizenship and student leadership in the forestry program, and commitment to the profession of forestry. Brendan received a technical diploma in forest technology at B.C.I.T. in 1999 before enrolling in the B.Sc. Forest Management program at the Uni-

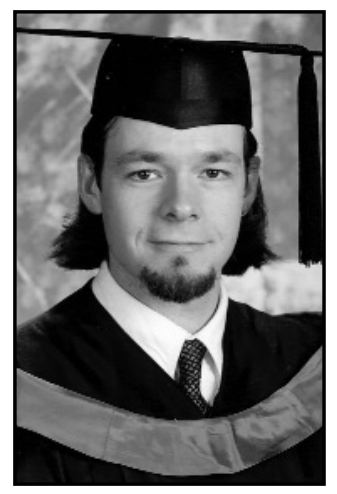
versity of Alberta. Brendan has worked with the forest sector in B.C. and Alberta in a forest engineering, silvicultural, and research capacity. While at the University of Alberta, Brendan was a student representative of the Forest Management program on faculty council. Brendan graduated from the Forest Management program this year with distinction and has placed on the Dean's list for the past two years. He has been the recipient of numerous University of Alberta awards for academic excellence in his forestry program.

Brendan has particular interests in forest hydrology and watershed management and is presently beginning an M.Sc. program in forest hydrology focussed on hydrologic recovery of boreal aspen after disturbance. The faculty wish Brendan all the best in his M.Sc. program in his career beyond.

\section{Stephen White}

University of British Columbia

I am a graduate of the Wood Products Processing (WPP) Program, part of the Faculty of Forestry at UBC. Upon entering the program in 1997, I immediately became active in residence life, in voluntary opportunities such as music and drama productions and in sports on campus (Junior Varsity and intramurals volleyball, basketball, soccer, ball hockey, ultimate, and UBC's infamous Storm the Wall).

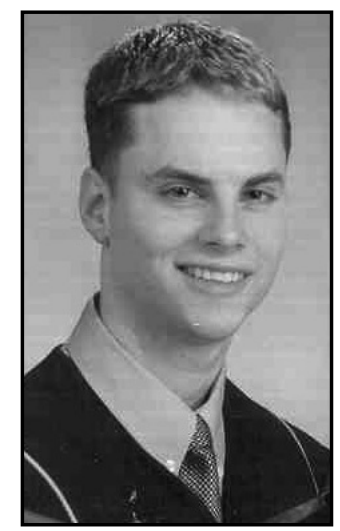

Through the WPP co-op program, I have already managed to accumulate twenty months' of relevant work experience all over Canada, at Riverside Forest Products (Kelowna, BC), Palliser Furniture (Winnipeg, MB), Interforest Veneer (Durham, ON), and Raywal Kitchens (Thornhill, ON). Together with a Minor in Commerce, I wish to pursue a career in the business and marketing side of the valueadded wood sector. After gaining work experience for a few years, I plan to complete an MBA in Strategic Management.

The road ahead, I hope, will be as rewarding and challenging as the road I am travelling now with a bright and hard-working group of fellow graduates, friends that I look forward to working with in the future. None of us could have completed this journey successfully without the Faculty of Forestry at UBC and its state-of-the-art facilities, an expert and supportive staff, and industry partners across Canada.

Canadian Institute of Forestry, thank you for supporting and encouraging a new generation of graduates. Count on us. We are ready to contribute our best to Canada's strong and proud forest and wood industry.

\section{David De Geus \\ University of New Brunswick}

UNB's Gold Medal winner is David De Geus from Nova Scotia. David graduated from Acadia University in 1997 with a degree in Honours Biology and will graduate from UNB in 2002 with a Bachelor of Science in Forest Engineering.

David has worked with Weyerhaeuser (Saskatchewan) for the past two summers and also completed an additional work term with that company. David is going back to work in western Canada this summer and then intends to do some traveling.

David has helped the Faculty of Forestry and Environmental Management as a Teaching Assistant. He was the Faculty's student representative to the 2000 CIF-AGM, and has distinguished himself by playing varsity-level soccer in each of his years at UNB. He was an Academic All Canadian in 1998, 


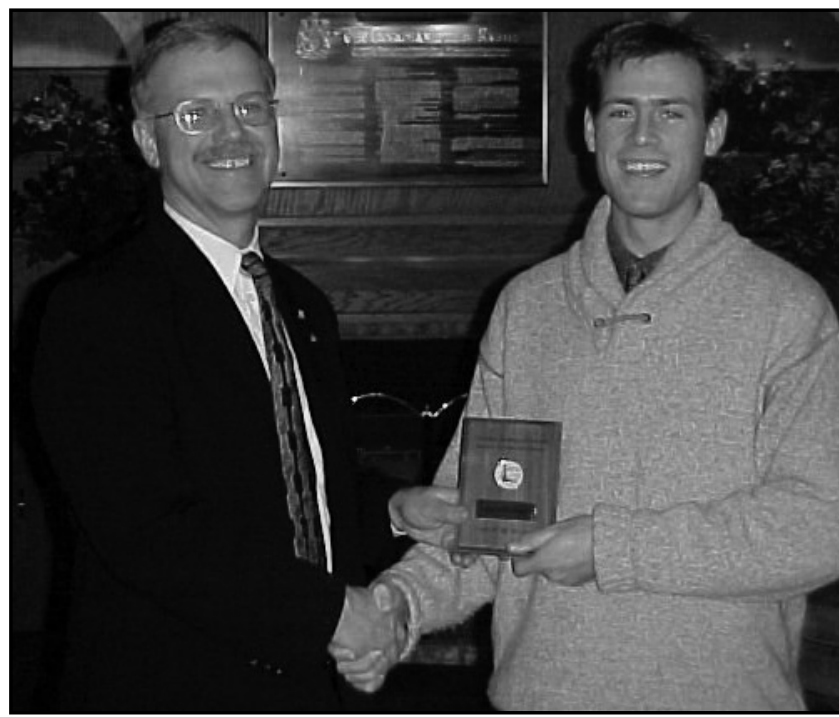

Len Moores (L), David DeGeus (R).

received the UNB Merit Award in 1999, and a Canada Millennium Scholarship in 2000.

Mr. De Geus is a credit to his school and will be a credit to his profession and to CIF.

Gretchen Prystawik

University of Northern British Columbia

Before coming to UNBC, Gretchen Prystawik graduated from Selkirk College with a Forestry Technical Diploma in 1999 on the President's Honour Roll and was awarded the William Barchard Harry Gairns presents medal to Gretchen Prystawik. Scholarship. One

of her former instructors provided the following comments.

"Gretchen was an exceptional student and class leader. A constantly interested and inquisitive learner, she was passionate about the natural world and the practice of forestry. Her happy and positive disposition was a fixture in class and in the field. Her attitude had a very positive impact on her classmates (and instructors) and contributed to very productive learning environment at Selkirk. She once packed an entire birthday cake for a friend with candles on one of my notoriously long and physically demanding January labs on snowshoes. At some point, she lit the candles undetected by the rest of the class, and appeared singing Happy Birthday."

Gretchen started UNBC in the fall of 2000, and completed her university career with a 4.0 GPA. She has had a very positive influence and made many contributions to student life during her time at UNBC. For example, she worked particularly hard on planning the 2002 CIF Ring Ceremony. Her work experience demonstrates that Gretchen has set out to acquire as many different experiences as possible. She worked as a contract supervisor, surveyor, timber cruiser, beetle prober, and tree planter to name a few forestry-related jobs. She has also worked for a remote fishing lodge, UNBC faculty members, and the McLeod Lake Band. Gretchen has also contributed to the wider community in several ways. She volunteered as an adult literacy tutor, is an English as a Second Language conversational tutor, and also tutors in the German language. Apparently she speaks French as well.

The CIF Gold Medal is well deserved. Congratulations Gretchen.

\section{CIF/IFC MASTERCARD}

The Canadian Institute of Forestry/Institut forestier du Canada (CIF/IFC) is pleased to be working with MBNA to offer a CIF/IFC Mastercard to their members. Every time you use the card, you will raise the profile of $\mathrm{CIF/IFC} \mathrm{and} \mathrm{their} \mathrm{members} \mathrm{as} \mathrm{the} \mathrm{"voice} \mathrm{of}$ forest practitioners" and it will also provide benefits to the Institute to further CIF/IFC programs. For more information or to apply today please call 1-800-416-6345.

\section{LA CARTE MASTERCARD CIF/IFC}

Le Canadian Institute of Forestry / Institut forestier du Canada (CIF/IFC) a le plaisir d'annoncer la collaboration de MBNA dans le but d'offrir une carte Mastercard CIF/IFC à ses membres. Chaque fois que vous utilisez la carte, vous ferez en sorte d'accroitre l'importance de l'Institut et de ses membres en tant que "porte-parole des praticiens de la foresterie" et vous permettrez à l'Institut de cumuler des bénéfices qui serviront à financer ses programmes. Pour de plus amples informations ou pour compléter une demande d'adhésion, veuillez composer le 1-800-416-6345, dès aujourd'hui.

\section{Davis \& Company}

\author{
BARRISTERS AND SOLICITORS
}

A CIF/IFC Corporate Sustaining Member 